\title{
Composição fotográfica oriental: um estudo sobre as imagens dos imigrantes japoneses em Londrina
}

\author{
Autor: MuriloAlves de Almeida Ito \\ Orientador: Alberto Carlos Augusto Klein
}

\begin{abstract}
Resumo: Esta dissertação propõe compreensão dos mecanismos que agem no momento da captura fotográfica; o recorte é a análise das imagens fotográficas dos imigrantes japoneses, no desenvolvimento da fotografia no município de Londrina-PR, entre os anos de 1930 a 1960. Tem o objetivo de analisar as fotografias e detectar qual dos três fatores sinédoque condicionantes agiu sobre os fotógrafos japoneses na captura fotográfica. Os fatores são: $1^{\circ}$ Fator Sinédoque Condicionante-Alfabetização Gramatical (os elementos da imagem são enquadrados inconscientemente pela direção inicial da alfabetização do idioma do indivíduo, ou seja da esquerda para direita ou da direita para a esquerda). $2^{\circ}$ Fator Sinédoque CondicionanteManual Kodak (os elementos da imagem são enquadrados inconscientemente no centro do fotograma por paradigma e também por uma imposição da limitação técnica da época, que orientava centralizar o objeto principal para preservar um registro seguro do evento, pois corria-se o risco de queimar as bordas da imagem). $3^{\circ}$ Fator Sinédoque Condicionante - Tecnologia + Regra dos Terços (os elementos da imagem são enquadrados conscientemente em qualquer parte do fotograma, sendo possível através da tecnologia preencher as bordas do fotograma, somadas as opções de posicionamento dos objetos nos pontos áureos, revelando um padrão gráfico sintonizado com a harmonia estética).
\end{abstract}

Palavras-chave: Fotografia. Imagens fotográficas. Imigrantes japoneses Londrina (PR). Comunicação visual. Fotogramas. 


\title{
The transformations of Brazillian television news and its implications on local daily newscast: a study of Paraná TV $1^{a}$ Edição
}

\begin{abstract}
This essay proposes the comprehension of mechanisms that act in the right moment when the picture is taken; the profile is the analysis of photographic images from Japanese immigrants in the development of the photographs in Londrina City - state of Paraná, between 1930 and 1960. It aims to analyze the photographs and verify which of the three conditioning synecdoche factors acted on the Japanese photographers in the photo capture. The factors are: 1st Conditioning Synecdoche Factor - Grammar Literacy (the image elements are unconsciously framed by the initial direction of the individual language literacy, or from the left to the right or from the right to the left). 2nd Conditioning Synecdoche Factor - Kodak Manual (the image elements are unconsciously framed on the center of the frame by paradigm and also by a technical limitation imposition from the time, that conducted centering the main object to preserve a secure register of the event, once there was a risk of burning the images edge). 3rd Conditioning Synecdoche Factor - Technology + Rule of Thirds (the image elements are consciously framed in any part of the frame since it's possible to fulfill the edges of the frame by technology, added to the options of positioning the objects in the golden ratio spots, revealing a graphic pattern tuned with the aesthetic harmony).
\end{abstract}

Keywords: Photography. Photographic images. Visual communication. Photograms.

Dissertação completa disponível em: http://www.bibliotecadigital.uel.br/ document/?view $=$ vtls000185908 